\title{
Effect of Gaseous Ozone on Listeria monocytogenes Planktonic Cells and Biofilm: An In Vitro Study
}

\author{
Felice Panebianco, Selene Rubiola $\mathbb{D}^{\mathbb{D}}$, Francesco Chiesa * ${ }^{\mathbb{D}}$, Tiziana Civera and Pierluigi Aldo Di Ciccio \\ Department of Veterinary Sciences, University of Turin, Largo Braccini 2, Grugliasco, 10095 Turin, Italy; \\ felice.panebianco@unito.it (F.P.); selene.rubiola@unito.it (S.R.); tiziana.civera@unito.it (T.C.); \\ pierluigialdo.diciccio@unito.it (P.A.D.C.) \\ * Correspondence: francesco.chiesa@unito.it; Tel.: +39-0116709334
}

Citation: Panebianco, F.; Rubiola, S.; Chiesa, F.; Civera, T.; Di Ciccio, P.A. Effect of Gaseous Ozone on Listeria monocytogenes Planktonic Cells and Biofilm: An In Vitro Study. Foods 2021, 10, 1484. https://doi.org/10.3390/ foods10071484

Academic Editors: Fernando Pérez-Rodriguez and Araceli Bolívar

Received: 28 May 2021

Accepted: 23 June 2021

Published: 26 June 2021

Publisher's Note: MDPI stays neutral with regard to jurisdictional claims in published maps and institutional affiliations.

Copyright: (c) 2021 by the authors. Licensee MDPI, Basel, Switzerland. This article is an open access article distributed under the terms and conditions of the Creative Commons Attribution (CC BY) license (https:// creativecommons.org/licenses/by/ $4.0 /)$.

\begin{abstract}
Among food-borne pathogens, Listeria monocytogenes continues to pose concerns to food business operators due to its capacity to form biofilm in processing environments. Ozone may be an eco-friendly technology to control microbial contaminations, but data concerning its effect on Listeria monocytogenes biofilm are still limited. In this study, the effect of gaseous ozone at $50 \mathrm{ppm}$ on planktonic cells and biofilm of reference and food-related Listeria monocytogenes strains was evaluated. Ozone caused a reduction in microbial loads of $3.7 \pm 0.4$ and $3.9 \pm 0.4 \log 10 \mathrm{CFU} / \mathrm{mL}$ after 10 and $30 \mathrm{~min}$, respectively. A complete inactivation of planktonic cells after $6 \mathrm{~h}$ of treatment was observed. Biofilm inhibition and eradication treatments $(50 \mathrm{ppm}, 6 \mathrm{~h})$ resulted in a significant decrease of the biofilm biomass for $59 \%$ of the strains tested, whilst a slight dampening of live cell loads in the biofilm state was observed. In conclusion, gaseous ozone is not sufficient to completely counteract Listeria monocytogenes biofilm, but it may be useful as an additional tool to contrast Listeria monocytogenes free-living cells and to improve the existing sanitization procedures in food processing environments.
\end{abstract}

Keywords: antimicrobial; biofilm; Listeria monocytogenes; ozone; eco-friendly technology; foodborne pathogens; food processing environment; planktonic cells; food industries; food safety

\section{Introduction}

Despite the regular application of sanitization plans by food business operators (FBO), bacterial biofilms are commonly found in food processing environments [1]. Biofilms allow microorganisms to better resist harsh environmental conditions, causing negative effects in food facilities, including lower industrial operational efficiency and contaminations of the final product with consequent issues related to its shelf life and safety $[2,3]$.

Among biofilm-forming food-borne pathogens, Listeria monocytogenes represents an important safety concern. L. monocytogenes is a ubiquitous Gram-positive bacterium responsible for human listeriosis [4], one of the most serious food-borne diseases with the highest case fatality (17.6\%) and which showed a significant increasing trend in the last years [5]. This pathogen can survive and grow in a wide range of foods, such as dairy, meat, seafood and vegetable products, with a high incidence especially in ready-to-eat (RTE) foods [6,7]. The processing environment is considered the most likely source of foodstuffs contamination by L. monocytogenes as the pathogen, when organized in biofilm, can persist for months or even years on surfaces representing a source of recurrent contaminations [8-13].

In food processing industries, chemical biocides are commonly used in order to control microbial contamination and biofilm. However, there are several concerns related to the intensive and prolonged use of these substances. Long-term exposure to antimicrobial agents, for example, may increase the tolerance of microorganisms to certain compounds and lead to a phenomenon known as antimicrobial cross-resistance [14-17]. In addition, the most commonly used biocide products may have an environmental and human health impact [18]. Among the innovative anti-biofilm strategies [2,19-22], ozone is considered a promising eco-friendly technology as it spontaneously breaks down into oxygen and does 
not leave harmful residues on food contact surfaces or in the finished products [23-25]. With regard to this, ozone has a reduced environmental impact compared to other chemicals employed in food processing environments and its effectiveness against a wide range of microorganisms is well documented $[18,26]$. The future possible application of this technology in food processing environments has been thoroughly reviewed in the last years [26-29]. However, data concerning the action of ozone on microbial biofilm are still scarce. Few studies have investigated the effect of ozone treatment on sessile forms of L. monocytogenes [18,30-32]. Ozone molecules in gaseous state have a longer half-life and higher diffusion than the molecules in aqueous form [33]. This means that ozone gas may be used to control L. monocytogenes biofilm in hard-to-reach areas within food processing environments, such as niches and other "dead zones", where the pathogen can persist [34]. Recently, several studies have highlighted that ozone gas may be effective in controlling microbial contamination and biofilms in the food industry, especially when used in high concentrations and for long treatment times $[18,23,30,31]$. In order to minimize health risks for operators due to the toxicity of ozone, this technology might be applied at the end of the production day, during the weekly closing days and in the absence of personnel $[18,23]$.

Previous studies have shown that growth dynamics, biofilm formation abilities and stress resistance may vary among different strains belonging to L. monocytogenes species [35-40] due to the presence of several genes and/or accessory genetic elements, including plasmids, prophages, stress-survival islets, etc. [41-45]. In view of this strain variability, experiments by using reference and wild-type L. monocytogenes strains are needed to assess the potential effect of an anti-biofilm technology.

Therefore, the aim of this study was to evaluate the effectiveness of gaseous ozone (50 ppm) treatment against biofilm and planktonic cells among reference and food-related L. monocytogenes strains.

\section{Materials and Methods}

\subsection{Bacterial Strains}

A total of 22 L. monocytogenes isolates were included in this study (Table 1). Two reference strains (ATCC 19112, known for its adherence characteristics; ATCC 7644, known as a strong biofilm producer) $[46,47]$ and 20 completely sequenced (whole genome sequencing) wild strains isolated from dairy environments (5), meat environments (5), dairy products (5) and meat products (5) in food industries located in Piedmont (Italy) (Collection of the Department of Veterinary Sciences, University of Turin) were used for experimental trials.

\subsection{Screening of Biofilm Forming Strains: Micro-Method Assays}

The biofilm capacity of all strains was assessed by using the micro-method assay described by Stepanovic at al. [48]. Briefly, overnight cultures $\left(37^{\circ} \mathrm{C}\right)$ of each strain cultivated in brain heart infusion (BHI) broth (Oxoid, Milan, Italy) were diluted to obtain an optical density (OD) at $550 \mathrm{~nm}$ (Pharmacia Biotech Ultrospec-3000, Biochrom Ltd., Cambridge, UK) comparable to the $0.5 \mathrm{McFarland}$ standard (cell concentration of about $8 \log 10 \mathrm{CFU} / \mathrm{mL}$ ). Subsequently, dilutions (1:100) of cultures were added in each well $(0.2 \mathrm{~mL}$ in triplicate for each strain) of 96-well polystyrene microplates (Sarstedt, Nümbrecht, Germany), while the negative control wells contained the uninoculated broth. Microplates were then incubated at $37^{\circ} \mathrm{C}$ for $24 \mathrm{~h}$. After the incubation, the BHI broth was discarded and wells were washed thrice with $0.3 \mathrm{~mL}$ of sterile phosphate buffer saline solution (PBS, pH 7.3 \pm 0.2 ; Oxoid). Biofilms were heat-fixed at $60{ }^{\circ} \mathrm{C}$ for $1 \mathrm{~h}$ and stained with $0.15 \mathrm{~mL}$ of a $2 \% w / v$ crystal violet solution (Chem-lab, Zedelgem, Belgium) for $15 \mathrm{~min}$. After staining, the solution was removed, wells were washed with distilled water and dried at $37^{\circ} \mathrm{C}$ for $15 \mathrm{~min}$. To quantify the biofilm formation, $0.15 \mathrm{~mL}$ of $95 \%$ ethanol solution (Honeywell, Charlotte, $\mathrm{NC}$, USA) were added to each well and the absorbance of the destaining solution was measured at $595 \mathrm{~nm}$ (iMark plate reader, Bio-Rad, Sydney, NSW, Australia). An average OD value was calculated for each strain (OD-S), while the optical density of the negative control (OD-C) was calculated by using the mean values of all negative control wells plus 
three standard deviations. The strains were classified as weak (OD-C $<$ OD-S $\leq 2 \times$ OD-C), moderate $(2 \times$ OD-C $<$ OD-S $\leq 4 \times$ OD-C), strong $(4 \times$ OD-C $<$ OD-S) and no (OD-S $\leq$ OD-C) biofilm producers.

Table 1. Characteristics of L. monocytogenes strains used in the present study.

\begin{tabular}{|c|c|c|c|c|c|c|c|}
\hline Category & $\begin{array}{l}\text { Strain ID } \\
\text { (Internal) }\end{array}$ & $\begin{array}{l}\text { Strain ID } \\
(\mathrm{NCBI})^{1}\end{array}$ & Source & Lineage & Serogroup & $\begin{array}{l}\text { Sequence } \\
\text { Type (ST) }\end{array}$ & $\begin{array}{c}\text { Clonal } \\
\text { Complex (CC) }\end{array}$ \\
\hline \multirow[t]{2}{*}{ ATCC } & ATCC 7644 & ATCC 7644 & Human & II & IIc & 122 & 9 \\
\hline & ATCC 19112 & WSLC1001 & Human & II & IIC & 12 & 7 \\
\hline \multirow[t]{10}{*}{ Dairy } & 17 & CFSAN045778 & Product & II & IIa & 9 & 9 \\
\hline & 25 & CFSAN045791 & Product & II & IIc & 9 & 9 \\
\hline & 76 & CFSAN044775 & Product & II & IIc & 9 & 9 \\
\hline & G40 & CFSAN044840 & Product & II & IIa & 325 & 31 \\
\hline & G52 & CFSAN044807 & Product & II & IIa & 325 & 31 \\
\hline & 7 & CFSAN045850 & $\begin{array}{l}\text { Production } \\
\text { Environment }\end{array}$ & II & IIa & 325 & 31 \\
\hline & 18 & CFSAN045794 & $\begin{array}{l}\text { Production } \\
\text { Environment }\end{array}$ & II & IIa & 9 & 9 \\
\hline & 40 & CFSAN044857 & $\begin{array}{l}\text { Production } \\
\text { Environment }\end{array}$ & II & IIa & 325 & 31 \\
\hline & G46 & CFSAN044805 & $\begin{array}{l}\text { Production } \\
\text { Environment }\end{array}$ & II & IIa & 325 & 31 \\
\hline & G69 & CFSAN044813 & $\begin{array}{l}\text { Production } \\
\text { Environment }\end{array}$ & II & IIa & 325 & 31 \\
\hline \multirow[t]{10}{*}{ Meat } & 16 & CFSAN045938 & Product & II & IIa & 325 & 31 \\
\hline & 20 & CFSAN045829 & Product & II & IIa & 9 & 9 \\
\hline & 36 & CFSAN044741 & Product & II & IIc & 9 & 9 \\
\hline & 38 & CFSAN044748 & Product & II & IIc & 9 & 9 \\
\hline & 64 & CFSAN044767 & Product & II & IIc & 9 & 9 \\
\hline & 1 & CFSAN046012 & $\begin{array}{l}\text { Production } \\
\text { Environment }\end{array}$ & II & IIc & 9 & 9 \\
\hline & 2 & CFSAN045995 & $\begin{array}{l}\text { Production } \\
\text { Environment }\end{array}$ & II & IIa & 325 & 31 \\
\hline & 6 & CFSAN045858 & $\begin{array}{l}\text { Production } \\
\text { Environment }\end{array}$ & II & IIc & 9 & 9 \\
\hline & 13 & CFSAN045971 & $\begin{array}{l}\text { Production } \\
\text { Environment }\end{array}$ & II & IIa & 9 & 9 \\
\hline & 37 & CFSAN046048 & $\begin{array}{l}\text { Production } \\
\text { Environment }\end{array}$ & II & IIc & 9 & 9 \\
\hline
\end{tabular}

${ }^{1}$ ID of the strains in the NCBI database (https:/ / www.ncbi.nlm.nih.gov/; accessed on 20 May 2021).

\subsection{Biofilm Production Quantification: Macro-Method Assays}

\subsubsection{Biofilm Production Indices (BPIs)}

The biofilm production index (BPI) of each strain was calculated by using the macromethod assay following Di Bonaventura et al. [9] with some modifications. In detail, overnight cultures $\left(37^{\circ} \mathrm{C}\right)$ of each strain in BHI broth (Oxoid) were washed thrice with a PBS solution (Oxoid), centrifugated (4000 rpm for $10 \mathrm{~min}$; ALC Multispeed PK121, ALC International srl, Cologno Monzese, Italy) three times and then re-suspended in BHI broth (Oxoid). Cultures were diluted to reach an OD of approximately 0.125 at $550 \mathrm{~nm}$ (Pharmacia Biotech Ultrospec-3000, Biochrom Ltd.), corresponding to a cell concentration of about $8 \log 10 \mathrm{CFU} / \mathrm{mL}$. Three milliliters of each diluted culture were added ( 3 wells for each strain) to polystyrene tissue culture plates (growth area $=8.87 \mathrm{~cm}^{2}$; Sarstedt), then incubated at $37^{\circ} \mathrm{C}$ for $24 \mathrm{~h}$. After incubation, BHI broth (Oxoid) was removed using a sterile Pasteur pipette and each well was washed three times with $3 \mathrm{~mL}$ of sterile PBS (Oxoid) to eliminate non-adherent cells. The formed biofilm was fixed at $60^{\circ} \mathrm{C}$ for $1 \mathrm{~h}$ and stained with $3 \mathrm{~mL}$ of a $2 \%$ crystal violet solution (95\% ethanol, Honeywell; $2 \%$ crystal violet, Chem-lab) for $20 \mathrm{~min}$. After staining, wells were washed three times with distilled water 
and dried at $37^{\circ} \mathrm{C}$ for $15 \mathrm{~min}$. Then, $3 \mathrm{ml}$ of a $33 \%$ acetic acid (Merck, Darmstadt, Germany) solution were added to each well. After $20 \mathrm{~min}, 0.2 \mathrm{~mL}$ from each sample were transferred to a 96-well microtiter plate (Sarstedt) and the OD level of the destaining solution was measured at $490 \mathrm{~nm}$. Results were normalized calculating the BPIs considering the growth area of each well $\left(8.87 \mathrm{~cm}^{2}\right)$ (Equation (1)):

$$
\text { BPIs }=\left(\frac{\text { ODmean }}{\text { biofilm surface }\left(\mathrm{mm}^{2}\right)}\right) \times 1000
$$

\subsubsection{Quantification of Viable Bacteria in the Biofilm}

Viable bacteria in biofilm state (macro-method assay) were counted after mechanical scraping of adherent cells in each well. In detail, overnight cultures $\left(37^{\circ} \mathrm{C}\right)$ of each strain in BHI broth (Oxoid) were washed, centrifugated, diluted and added (3 wells for each strain) to polystyrene tissue culture plates (Sarstedt) as previously described (see Section 2.3.1). After incubation $\left(37^{\circ} \mathrm{C}\right.$ for $24 \mathrm{~h}$ ), BHI broth (Oxoid) was removed using a sterile Pasteur pipette and each well was washed thrice with $3 \mathrm{~mL}$ of sterile PBS (Oxoid) to eliminate non-adherent cells. Then, $3 \mathrm{ml}$ of PBS (Oxoid) were added to each well and adherent cells were removed by scraping (mechanical action) as described by Zand et al. [49]. Bacterial suspensions were diluted (1:10) in sterile physiological saline peptone (PS) $(0.85 \% \mathrm{NaCl}$, Carlo Erba, Italy; $0.1 \%$ Bacteriological Peptone, Oxoid) and inoculated by surface plating on $\mathrm{BHI}$ agar (Oxoid) plates, then incubated at $37^{\circ} \mathrm{C}$ for $48 \mathrm{~h}$. The L. monocytogenes counts were expressed as Log10 CFU/mL.

\subsection{Ozonization Assays}

\subsubsection{Treatment Chamber and Experimental Conditions}

An in vitro simulation system was designed to test the pathogen inactivation and the anti-biofilm activity of ozone $\left(\mathrm{O}_{3}\right)$ gas under different treatment conditions. A graphical representation was created with BioRender (https: / / biorender.com/; accessed on 27 May 2021) [50] (Figure 1). The system was equipped with: $\mathrm{O}_{3}$ generator, $\mathrm{O}_{3}$ monitor and the source of oxygen and air gases used for $\mathrm{O}_{3}$ production. The ozone-inert plexiglass chamber (Biofresh Group Ltd., Northumberland, UK) was connected to an ozone generator (ModelLF5; Biofresh Group Ltd.) and gas injection was regulated by an ozone analyzer (UV-100, EcoSensor, Santa Fe, USA). A fan was placed in the chamber to allow a homogeneous distribution of the gas during each treatment. Containers with warm water were placed on the bottom in order to keep high $(\geq 90 \%)$ relative humidity $(\mathrm{RH})$, since the bactericidal effect of gaseous ozone seems to be linked with increasing RH (optimum level of 90-95\%, no effect below 50\%) [25]. All the experiments were performed at room temperature. A data logger (Testo $174 \mathrm{H}$, Testo AG, Lenzkirchen, Germany) was placed in the chamber to check temperature fluctuations and $\mathrm{RH}(\%)$ during treatments. The ozone treatments were performed with a high gas concentration (50 ppm). The effect on L. monocytogenes planktonic cells was firstly assessed during two short treatment times (10 min and $30 \mathrm{~min}$ ) since free cells are generally more susceptiblethan bacteria in biofilm, so short exposure times to high ozone concentrations should have caused a significant logarithmic reduction. Secondly, a long treatment $(6 \mathrm{~h})$ was carried out to test whether prolonged exposure could lead to a total inactivation of high planktonic cell loads. For the biofilm form, considering the literature data and the higher resistance to oxidative stress of cells in the sessile state compared to the planktonic forms [18,23,30-32], the ability of ozone gas to prevent and eradicate $L$. monocytogenes biofilm was tested only during a prolonged treatment time $(6 \mathrm{~h})$.

\subsubsection{Effect of Gaseous Ozone on L. monocytogenes Planktonic Cells}

L. monocytogenes strains were pre-cultured in tryptic soy broth (TSB-Oxoid) at $37^{\circ} \mathrm{C}$ overnight. Cultures were diluted (1:10) in sterile PS and appropriate dilutions were plated in duplicate on tryptic soy agar (TSA-Oxoid). Inoculated plates were submitted to treatments with gaseous ozone at $50 \mathrm{ppm}$ for 10,30 min and $6 \mathrm{~h}$. Inoculated TSA plates not 
submitted to ozonization were control tests. To enumerate L. monocytogenes cells, treated and control plates were incubated at $37^{\circ} \mathrm{C}$ for $24 / 48 \mathrm{~h}$. Bacterial counts, before and after the treatments, were performed to evaluate the logarithmic reduction $(\log 10 \mathrm{CFU} / \mathrm{mL})$ caused by ozone exposure.

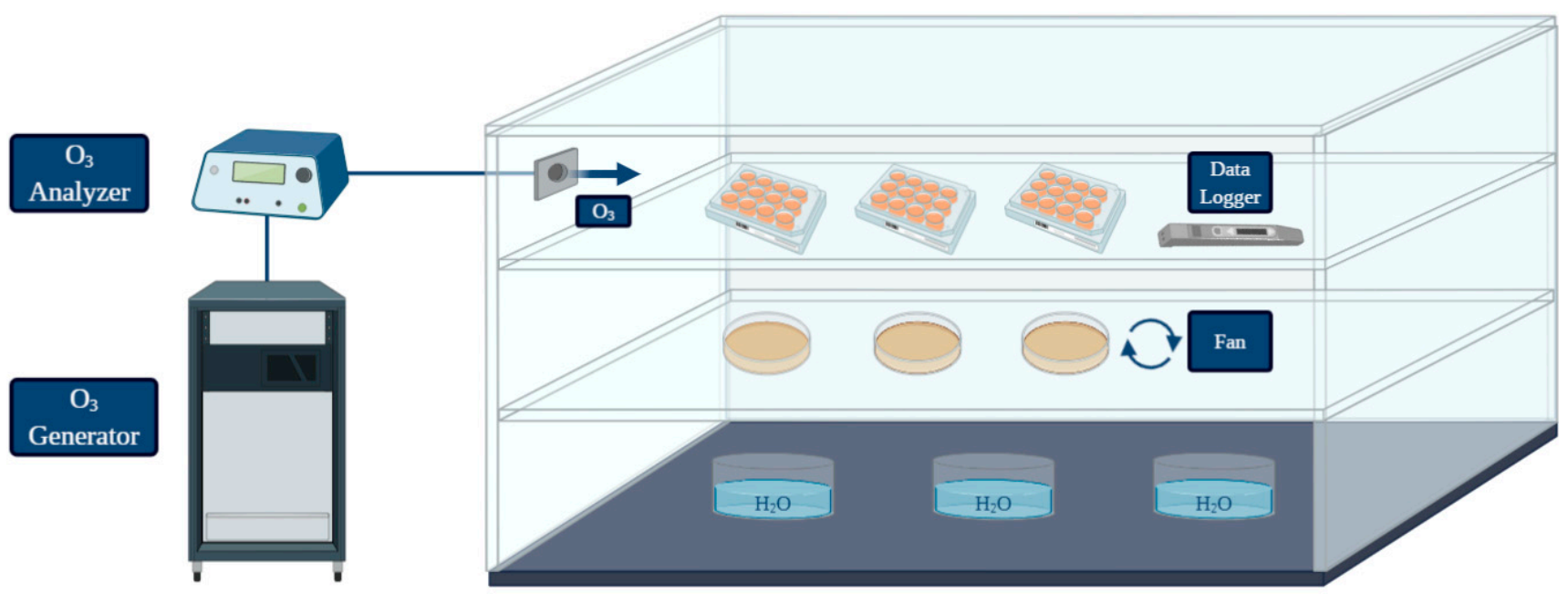

Figure 1. Graphical representation of the system used for the treatments performed in the present study (created with BioRender; https: / / biorender.com/; accessed on 27 May 2021).

\subsubsection{Biofilm Inhibition by Gaseous Ozone}

This experimental step was aimed at evaluating the capacity of gaseous ozone to affect the biofilm formation abilities of the strains. For this purpose, bacteria were preliminary exposed to the ozone treatments before the incubation of plates and the subsequent biofilm formation. This possible preventive activity of ozone was assessed following the methods previously described (macro-method assay; see Sections 2.3.1 and 2.3.2). In this case, the protocol was modified including an additional step (ozone gas treatment). Specifically, revitalized cultures were washed, centrifugated, resuspended, diluted and poured in polystyrene tissue culture plates (6-wells; Sarstedt). Plates were subjected to treatment with $50 \mathrm{ppm}$ of gaseous ozone for $6 \mathrm{~h}$ and incubated at $37^{\circ} \mathrm{C}$ for $24 \mathrm{~h}$. After incubation, BPIs and counts of viable adherent cells in the biofilm state were carried out as described before. Finally, BPIs and loads of viable adherent cells calculated were compared to those detected after the biofilm production assay (controls) to evaluate the effect of exposure to ozone gas.

\subsubsection{Biofilm Eradication by Gaseous Ozone}

These treatments were carried out to evaluate the effect of ozone gas on consolidated biofilms. Pre-formed biofilms of each strain were exposed to gaseous ozone to assess the eradication capacity of this technology. In this case, we also modified the previously described protocols (macro-method assay; see Sections 2.3.1 and 2.3.2) including an additional step (ozone gas treatment). Revitalized cultures were washed, centrifugated, resuspended, diluted, poured in polystyrene tissue culture plates and incubated at $37^{\circ} \mathrm{C}$ for $24 \mathrm{~h}$ to allow the biofilm formation. After incubation, $3 \mathrm{~mL}$ of $\mathrm{BHI}$ broth (Oxoid) were removed from each well and the cells organized in biofilm were exposed to $50 \mathrm{ppm}$ of gaseous ozone for $6 \mathrm{~h}$. After treatment, BPIs and viable adherent bacteria in the biofilm were quantified as described before. Finally, BPIs and loads of viable adherent cells calculated were compared to those detected after the biofilm production assay (controls) to evaluate the effect of exposure to ozone gas. 


\subsection{Statistical Analyses and Graphing}

To evaluate the effect of $\mathrm{O}_{3}$ on the pathogen in planktonic form (see Section 2.4.2), data were analyzed performing a two-way analysis of variance (ANOVA) followed by a Tukey's multiple comparison test $(p<0.05)$. As far as the anti-biofilm effect of $\mathrm{O}_{3}$ gas is concerned (see Sections 2.4.3 and 2.4.4), significant differences in BPIs before and after the ozone treatments were calculated performing a two-way ANOVA followed by a Dunnett's multiple comparison test $(p<0.05)$, while the Tukey's multiple comparison test $(p<0.05)$ was applied to analyze the data on viable adherent cells before and after the ozone exposure. Statistical analyses and graphing were conducted with GraphPad Prism version 9.0.0 (GraphPad Software, San Diego, CA, USA).

\section{Results}

\subsection{Screening of Biofilm Forming Strains: Micro-Method Assays}

All L. monocytogenes were previously classified as biofilm-forming strains. In this study, $18 \%(4 / 22)$ were strong biofilm producers, $18 \%(4 / 22)$ moderate biofilm producers and $64 \%(14 / 22)$ weak biofilm producers.

\subsection{Effects of $\mathrm{O}_{3}$ on L. monocytogenes Planktonic Cells}

A reduction of L. monocytogenes loads was observed after the short-term (10 and $30 \mathrm{~min}$ ) and long-term $(6 \mathrm{~h})$ treatments with gaseous ozone at $50 \mathrm{ppm}$ compared to control samples (Table 2). Specifically, $10 \mathrm{~min}$ of treatment caused a mean logarithmic reduction of $3.7 \pm 0.4 \mathrm{Log} 10 \mathrm{CFU} / \mathrm{mL}$, while the mean logarithmic reduction of L. monocytogenes loads after $30 \mathrm{~min}$ of treatment was $3.9 \pm 0.4 \log 10 \mathrm{CFU} / \mathrm{mL}$. Significant differences in loads reduction between the two short-term treatments (10 and $30 \mathrm{~min})$ were observed for strain n.18 and n.20. The long-term exposure $(6 \mathrm{~h})$ led to a total inactivation of 17 strains $(77.3 \%$ of the 22 strains tested). Only for five strains (n.17, n.38, n.40, ATCC 7644, ATCC 19112; $22.7 \%$ of all strains) colonies grew in plates treated for $6 \mathrm{~h}$, while for the remaining strains loads were below the detection limit $(1 \log 10 \mathrm{CFU} / \mathrm{mL})$.

Table 2. Logarithmic reduction ( $\log 10 \mathrm{CFU} / \mathrm{mL}$ ) of L. monocytogenes planktonic cells after the ozone exposure $\left(\mathrm{O}_{3}=50 \mathrm{ppm} ; 10,30 \mathrm{~min}\right.$ and $\left.6 \mathrm{~h}\right)$ compared to control samples.

\begin{tabular}{|c|c|c|c|}
\hline \multirow[t]{2}{*}{ Strain ID } & \multicolumn{3}{|c|}{ Logarithmic Reduction ${ }^{1,2}$} \\
\hline & $10 \mathrm{~min}$ & $30 \mathrm{~min}$ & $6 \mathrm{~h}$ \\
\hline ATCC 7644 & $3.2 \pm 0.1^{\mathrm{a}}$ & $3.6 \pm 0.3^{a}$ & $7.2 \pm 0.1^{b}$ \\
\hline ATCC 19112 & $3.1 \pm 0.2^{\mathrm{a}}$ & $3.1 \pm 0.1^{\mathrm{a}}$ & $7.5 \pm 0.3^{b}$ \\
\hline 1 & $3.1 \pm 0.3^{a}$ & $3.5 \pm 0.3^{\mathrm{a}}$ & $\geq 7.7 \pm 0.1^{b}$ \\
\hline 2 & $3.9 \pm 0.1^{a}$ & $4.3 \pm 0.1^{\mathrm{a}}$ & $\geq 9.2 \pm 0.0^{b}$ \\
\hline 6 & $4.2 \pm 0.1^{\mathrm{a}}$ & $4.4 \pm 0.1^{\mathrm{a}}$ & $\geq 9.2 \pm 0.1^{b}$ \\
\hline 7 & $3.7 \pm 0.2^{\mathrm{a}}$ & $3.9 \pm 0.1^{a}$ & $\geq 9.0 \pm 0.1^{b}$ \\
\hline 13 & $4.1 \pm 0.1^{\mathrm{a}}$ & $4.0 \pm 0.2^{\mathrm{a}}$ & $\geq 9.2 \pm 0.1^{b}$ \\
\hline 16 & $3.3 \pm 0.2^{a}$ & $3.3 \pm 0.1^{a}$ & $\geq 8.2 \pm 0.0^{b}$ \\
\hline 17 & $3.6 \pm 0.0^{\mathrm{a}}$ & $3.5 \pm 0.1^{\mathrm{a}}$ & $7.4 \pm 0.1^{b}$ \\
\hline 18 & $4.5 \pm 0.1^{b}$ & $4.0 \pm 0.2^{\mathrm{a}}$ & $\geq 9.1 \pm 0.1^{\mathrm{c}}$ \\
\hline 20 & $3.6 \pm 0.1^{\mathrm{a}}$ & $4.2 \pm 0.1^{b}$ & $\geq 8.4 \pm 0.0^{\mathrm{c}}$ \\
\hline 25 & $3.5 \pm 0.4^{\mathrm{a}}$ & $3.5 \pm 0.1^{\mathrm{a}}$ & $\geq 8.2 \pm 0.1^{b}$ \\
\hline 36 & $3.3 \pm 0.1^{\mathrm{a}}$ & $3.7 \pm 0.1^{\mathrm{a}}$ & $\geq 8.7 \pm 0.1^{b}$ \\
\hline 37 & $4.1 \pm 0.1^{\mathrm{a}}$ & $4.2 \pm 0.0^{\mathrm{a}}$ & $\geq 9.2 \pm 0.0^{b}$ \\
\hline 38 & $4.1 \pm 0.3^{\mathrm{a}}$ & $4.1 \pm 0.3^{\mathrm{a}}$ & $7.2 \pm 0.4^{b}$ \\
\hline 40 & $4.1 \pm 0.3^{\mathrm{a}}$ & $3.9 \pm 0.1^{\mathrm{a}}$ & $8.2 \pm 0.1^{b}$ \\
\hline 64 & $3.7 \pm 0.2^{\mathrm{a}}$ & $4.1 \pm 0.4^{\mathrm{a}}$ & $\geq 8.8 \pm 0.2^{b}$ \\
\hline 76 & $3.7 \pm 0.2^{\mathrm{a}}$ & $4.1 \pm 0.1^{\mathrm{a}}$ & $\geq 8.9 \pm 0.1^{b}$ \\
\hline G40 & $3.5 \pm 0.2^{\mathrm{a}}$ & $3.5 \pm 0.1^{\mathrm{a}}$ & $\geq 8.6 \pm 0.1^{b}$ \\
\hline
\end{tabular}


Table 2. Cont.

\begin{tabular}{cccc}
\hline Strain ID & Logarithmic Reduction ${ }^{\mathbf{1 , 2}}$ \\
\hline & $\mathbf{1 0} \mathbf{~ m i n}$ & $\mathbf{3 0 ~} \mathbf{~ i n}$ & $\mathbf{6 ~ h}$ \\
\hline G46 & $4.1 \pm 0.2^{\mathrm{a}}$ & $4.2 \pm 0.1^{\mathrm{a}}$ & $\geq 9.1 \pm 0.1^{\mathrm{b}}$ \\
$\mathrm{G} 52$ & $4.1 \pm 0.2^{\mathrm{a}}$ & $4.3 \pm 0.2^{\mathrm{a}}$ & $\geq 9.1 \pm 0.2^{\mathrm{b}}$ \\
$\mathrm{G} 69$ & $3.9 \pm 0.0^{\mathrm{a}}$ & $4.1 \pm 0.1^{\mathrm{a}}$ & $\geq 9.1 \pm 0.0^{\mathrm{b}}$ \\
\hline
\end{tabular}

${ }^{1}$ Average \pm Standard deviation of two replicates. ${ }^{2}$ Values followed by different small letters in the same row are significantly different according to Tukey's multiple comparison test $(p<0.05)$.

\subsection{Effect of $\mathrm{O}_{3}$ on Biofilm}

3.3.1. Effect on the Biofilm Biomass

BPIs of 13 strains ( $59 \%$ of the 22 strains tested) were significantly lower after the inhibition and/or eradication treatments compared to the control BPIs (Figure 2). Regarding the inhibition treatments (bacteria exposed to ozone before the biofilm formation; see Section 2.4.3), a reduction of BPIs was observed in $27 \%$ (6/22) of L. monocytogenes strains, suggesting a reduced biofilm formation ability of these isolates after the preliminary exposure to ozone gas. An effect in both of inhibition and eradication (pre-formed biofilms exposed to ozone gas; see Section 2.4.4) of biofilm was observed in $32 \%(7 / 22)$ of L. monocytogenes strains. No effect was observed in $41 \%(9 / 22)$ of $L$. monocytogenes strains. Three strains showed significantly higher BPIs after the eradication treatments compared to the BPIs of the control.
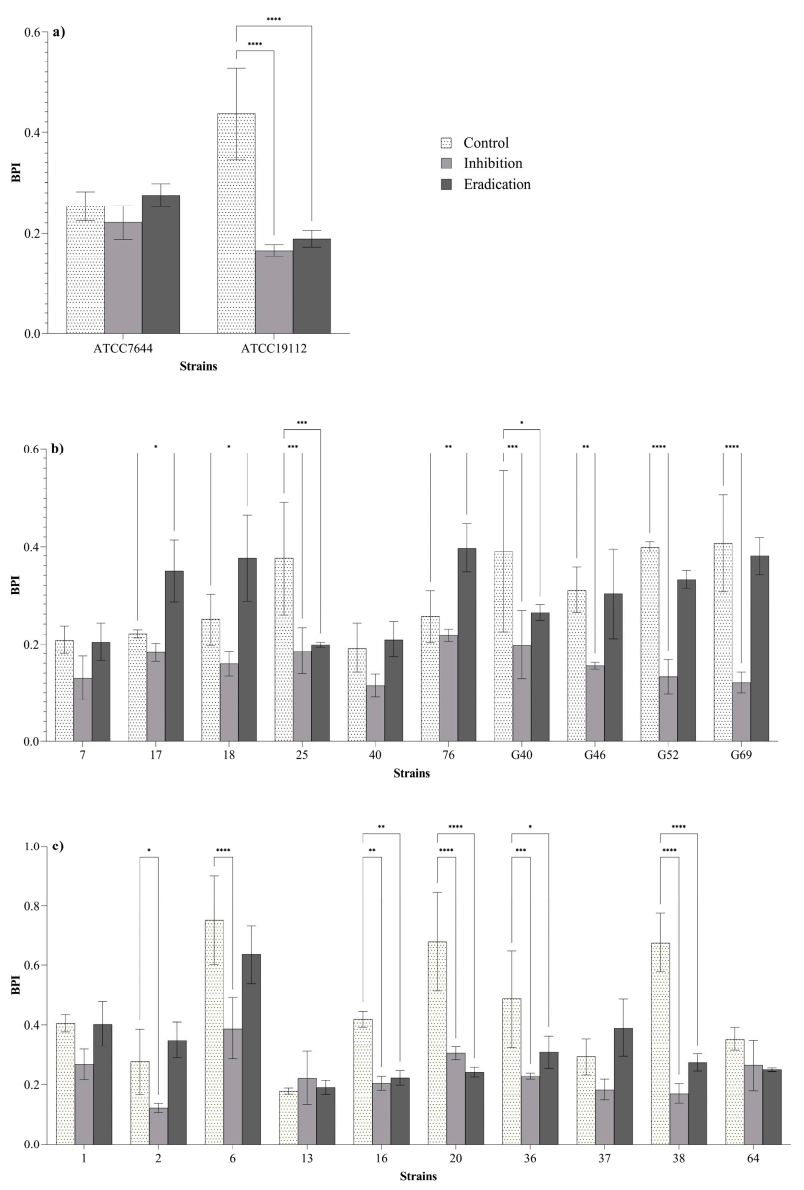

Figure 2. Biofilm production indices (BPIs) of ATCC (a), dairy-related (b) and meat-related (c) L. monocytogenes strains after the inhibition and eradication treatments (50 ppm of gaseous ozone for $6 \mathrm{~h})$ compared to control samples. Error bars indicate the standard deviation between three replicates. Asterisks indicate the significant differences according to the Dunnett's multiple comparison $(p<0.05)$. 


\subsubsection{Effect on Viable Biofilm-Detached Cells}

Outcomes of viable adherent cells counts after the ozone exposure compared to control samples are given in Table 3. After the inhibition treatments (bacteria exposed to ozone before the biofilm formation; see Section 2.4.3), the mean reduction of viable adherent cells was $0.7 \pm 0.4 \mathrm{Log} 10 \mathrm{CFU} / \mathrm{mL}$. After the eradication treatments (pre-formed biofilms exposed to ozone gas; see Section 2.4.4), instead, a mean reduction of $0.8 \pm 0.5 \mathrm{Log} 10 \mathrm{CFU} / \mathrm{mL}$ was detected. Significant differences in logarithmic reductions among inhibition and eradication treatments were observed for $37 \%(8 / 22)$ of L. monocytogenes strains.

Table 3. Logarithmic reduction ( $\log 10 \mathrm{CFU} / \mathrm{mL}$ ) of L. monocytogenes viable adherent cells after the inhibition and eradication of the biofilm forms $\left(\mathrm{O}_{3}=50 \mathrm{ppm} ; 6 \mathrm{~h}\right)$ compared to control samples.

\begin{tabular}{|c|c|c|}
\hline \multirow[t]{2}{*}{ Strain ID } & \multicolumn{2}{|c|}{ Logarithmic Reduction ${ }^{1,2}$} \\
\hline & Inhibition & Eradication \\
\hline ATCC 7644 & $0.6 \pm 0.1$ & $0.6 \pm 0.1$ \\
\hline ATCC 19112 & $0.7 \pm 0.1^{b}$ & $1.2 \pm 0.1^{\mathrm{a}}$ \\
\hline 1 & $1.0 \pm 0.0$ & $1.1 \pm 0.0$ \\
\hline 2 & $1.2 \pm 0.1$ & $1.1 \pm 0.1$ \\
\hline 6 & $0.4 \pm 0.1^{\mathrm{a}}$ & $0.1 \pm 0.1^{b}$ \\
\hline 7 & $1.3 \pm 0.1$ & $1.3 \pm 0.1$ \\
\hline 13 & $0.2 \pm 0.1$ & $0.2 \pm 0.1$ \\
\hline 16 & $1.1 \pm 0.1$ & $1.2 \pm 0.1$ \\
\hline 17 & $0.6 \pm 0.1^{b}$ & $0.9 \pm 0.1^{\mathrm{a}}$ \\
\hline 18 & $1.6 \pm 0.0$ & $1.7 \pm 0.1$ \\
\hline 20 & $0.6 \pm 0.0^{\mathrm{a}}$ & $0.1 \pm 0.0^{b}$ \\
\hline 25 & $0.9 \pm 0.0$ & $1.0 \pm 0.0$ \\
\hline 36 & $0.9 \pm 0.1^{b}$ & $1.2 \pm 0.1^{\mathrm{a}}$ \\
\hline 37 & $0.7 \pm 0.1$ & $0.6 \pm 0.1$ \\
\hline 38 & $0.7 \pm 0.1^{\mathrm{a}}$ & $0.3 \pm 0.2^{b}$ \\
\hline 40 & $0.1 \pm 0.1$ & $0.2 \pm 0.1$ \\
\hline 64 & $0.6 \pm 0.1$ & $0.4 \pm 0.1$ \\
\hline 76 & $0.6 \pm 0.1^{b}$ & $1.3 \pm 0.2^{\mathrm{a}}$ \\
\hline G40 & $0.9 \pm 0.0$ & $1.1 \pm 0.2$ \\
\hline G46 & $0.4 \pm 0.1$ & $0.6 \pm 0.1$ \\
\hline G52 & $1.0 \pm 0.1$ & $1.0 \pm 0.1$ \\
\hline G69 & $0.4 \pm 0.2^{\mathrm{a}}$ & $0.0 \pm 0.1^{b}$ \\
\hline
\end{tabular}

${ }_{1}^{1}$ Average \pm Standard deviation of three replicates. ${ }^{2}$ Values followed by different small letters in the same row are significantly different according to the Tukey's multiple comparison test $(p<0.05)$. Strain $\mathrm{n} .20=$ highest significant difference in logarithmic reduction in inhibition compared to eradication.

\section{Discussion}

Previous studies showed that the antimicrobial efficacy of treatments with gaseous ozone against planktonic and sessile cells is affected by the concentration and the treatment time. In regard to this, Guzzon et al. [51] demonstrated that prolonged exposure (up to $6 \mathrm{~h}$ ) to gaseous ozone reduced the total microbial loads on wooden shelves used for the ripening of traditional Italian cheeses. A recent study carried out by Botta et al. [23] in slaughterhouse environments showed that ozone gas could be an efficient adjunct sanitizing method if used at concentrations of 20 and $40 \mathrm{ppm}$ for $12 \mathrm{~h}$. As for L. monocytogenes, previous research reported that high levels of ozone are required to obtain an effect against biofilms formed by this pathogen. Nicholas et al. [31] observed a mean reduction of $3.41 \log 10 \mathrm{CFU} / \mathrm{cm}^{2}$ for L. monocytogenes cells attached to stainless steel after a $1 \mathrm{~h}$ treatment with $45 \mathrm{ppm}$ of gaseous ozone, while a reduction less than $1 \log 10 \mathrm{CFU} / \mathrm{cm}^{2}$ was detected with $10 \mathrm{ppm}$ of ozone at the same time. On the contrary, the same microorganisms organized in biofilm were significantly more resistant after a treatment with ozone gas at $45 \mathrm{ppm}$ for $1 \mathrm{~h}$. Recently, Harada et al. [30] demonstrated the efficiency of gaseous ozone at high concentration (45 ppm) as a dry sanitizing method against L. monocytogenes biofilm. 
Based on these literature data, we decided to perform our experiment with a high ozone gas concentration ( $50 \mathrm{ppm}$ ) in order to evaluate its effect against $L$. monocytogenes isolates from food industries. Firstly, the effect of ozone gas for 10 and $30 \mathrm{~min}$ was assessed against $L$. monocytogenes planktonic cells. Both short exposure times at $50 \mathrm{ppm}$ resulted in a significant logarithmic reduction for all strains tested. After this step, the strains were exposed to ozone gas $(50 \mathrm{ppm})$ for $6 \mathrm{~h}$. This long treatment time resulted in a total inactivation of planktonic cells (see Section 3.2 and Table 2). These findings suggest that high concentrations of ozone in gaseous form may be applied to destroy L. monocytogenes planktonic cells in hard-to-reach areas within food processing environments. Therefore, a significant antimicrobial effect (reduction of $3.7 \pm 0.4 \log 10 \mathrm{CFU} / \mathrm{mL}$ and $3.9 \pm 0.4 \log 10 \mathrm{CFU} / \mathrm{mL}$ ) can be achieved even with short treatment times (10 and $30 \mathrm{~min}$ ).

Considering that bacteria in biofilm state are known to express a higher resistance to oxidative stress compared to the planktonic forms [18,23,30-32], biofilm inhibition and eradication tests were performed at $50 \mathrm{ppm}$ for $6 \mathrm{~h}$. All strains were previously classified as biofilm producers by using 96-well microtiter plates (micro-method assay; see Sections 2.2 and 3.1). In order to assess the effect of ozone gas treatment in prevention (biofilm-inhibition) and removal (biofilm-eradication) of biofilm, we used different methods to quantify the biofilm biomass and the loads of viable biofilm-detached cells (see Sections 2.4.3 and 2.4.4). In these experiments, the 6-well plates were selected to overcome the limitation of the basic microtiter plate (96-wells format) concerning the possible nutrient limitation and to maximize the exposure of sessile cells to ozone gas. In addition, we attempted to investigate the inhibition and eradication effect of ozone gas in conditions simulating those of food processing plants. With regard to this, the tests were carried out in BHI broth during the inhibition assay (see Section 2.4.3) and without drying the pre-formed biofilm in the eradication assay (see Section 2.4.4) while keeping the residual BHI broth in the wells. Organic matter, in fact, may persist on surfaces or niches after routine cleaning and disinfection activities in food processing environments. The response of L. monocytogenes in biofilm state compared to planktonic form (see Section 3.3 and Figure 2) was different. As previously reported by other authors, the bacteria organized in biofilm can increase their resistance to oxidative stress [18,32]. Regarding reference strains (strong biofilm producers), ozone exposure resulted in significant reductions of BPIs after the inhibition and eradication assays for strain ATCC 19112, whereas no effect was observed for strain ATCC 7644 (Figure 2a). Ozone gas caused significant reductions in BPIs after inhibition and/or eradication assays in $60 \%(6 / 10)$ of isolates from meat products and meat processing environments (Figure 2c). As for L. monocytogenes isolates from dairy products and dairy processing environments, significant reductions in BPIs after inhibition and/or eradication assays were observed for $50 \%(5 / 10)$ of the strains (Figure $2 b)$. The results seem to suggest that dairy-related strains may be more resistant to oxidative stress than meat-related isolates. Environmental strains showed a higher tolerance to ozone exposure than food isolates (Figure $2 b, c)$. The latter outcome appears justifiable, since it has been demonstrated that environmental strains of L. monocytogenes can persist in food processing plants for months or years, developing a greater resistance to different types of stress and several antimicrobial compounds [10,15-17,36].

In order to evaluate the potential correlation between the reduction in BPIs and viable biofilm-detached cells after the ozone treatment, counts of adherent bacteria in established biofilms were performed. Outcomes showed a slight reduction of microbial loads for all strains after the ozone treatment compared to control samples. The cell reduction was not correlated with decreases in BPIs (see Section 3.3.2 and Table 3). As previously reported by several authors, the biofilm biomass is not linked to bacterial viability. The total biomass, as measured using the crystal violet staining method, includes live, un-culturable, dead bacteria and the extracellular polymeric matrix [52-54]. The lower BPIs observed for some strains after the inhibition assay may indicate a reduced capacity of cells to produce the extracellular polymeric matrix after a preliminary exposure to oxidative stress. Similarly, BPIs obtained after the eradication of pre-formed biofilm indicated that the oxidative stress 
caused a significant reduction of the total biomass in biofilm with probable structural losses in the extracellular matrix. For three strains (n.17, n.18, n.76), BPIs were significantly higher than BPIs of the control after the eradication assays. We hypothesized that these strains developed a resistance as a response to the oxidative stress in the first hours during the exposure to ozone, increasing the production of extracellular matrix. As reported by Abeysundara et al. [55], some L. monocytogenes strains can increase their survival capacity at lethal oxidative stress when cells are preliminary exposed to sub-lethal oxidative stress. This phenomenon is certainly worrying and should be emphasized, even though it occurred only for three strains (13.6\% of the strains tested). Studies on more isolates are needed to understand the mechanisms behind this adaptation. This aspect is crucial to avoid that strains highly resistant to oxidative stress may be selected as a consequence of ozone treatments in the processing environments.

Our findings led to some discussion points on the real effectiveness of gaseous ozone against L. monocytogenes biofilm. Ozone gas was effective in reducing L. monocytogenes planktonic cells, whereas its action on these bacteria organized in biofilm seems limited and strain specific. To date, the great challenge in the food industry is to prevent and/or remove established L. monocytogenes biofilm. Our outcomes emphasized the limits of the use of ozone gas to mitigate L. monocytogenes biofilm. Regarding the methods used in our experiment, an indication on the effect of ozone gas against the total biofilm biomass can be obtained by using colorimetric staining assays. The reductions in BPIs were not linked to loads of viable biofilm-detached cells. Reductions in BPIs should certainly be taken in high regard since they indicate a potential action of ozone gas on the extracellular matrix which protects live cells from several stressful conditions (such as oxidative stress) [54]. However, counts of viable biofilm-detached cells demonstrated that bacteria could resist after substantial damages on the polymeric matrix keeping similar loads after ozone treatments. These results indicate that the application of gaseous ozone is not sufficient to counteract L. monocytogenes biofilm. Probably, ozone gas could be more effective on mixedspecies biofilms. In the food environment, L. monocytogenes can persist in dual-species biofilm with other bacterial genera, such as Pseudomonas spp. [56]. Considering the high activity of gaseous ozone against Pseudomonas spp. [57] and other food-related bacteria, its application may act selectively against one population in mixed-species biofilms causing damage on the biofilm structure and a subsequent loss of protection for the bacterial population less sensitive to the oxidative stress. In addition, the results obtained on planktonic forms suggest that a preventive application of ozone gas may be useful to avoid the organization in biofilm by L. monocytogenes free-living cells. In light of these findings and according to other authors [18,23], gaseous ozone could be useful as an additional tool to improve the existing cleaning and disinfection procedures to control microbial contamination in food processing environments.

In general, despite the unquestionable advantages of gaseous ozone as an antimicrobial agent with a low environmental impact, there are several limits regarding the practical application of this technology as an anti-biofilm agent in food processing plants. These concerns arise from the high concentrations and the long exposure time required to achieve a significant effect on L. monocytogenes biofilm [18,30,31]. High ozone levels, indeed, are dangerous for human health, so its potential application in food industries would be possible only during downtime periods and in the absence of operators [18]. In regard to this, the application of ozone gas for the disinfection of empty cheese ripening rooms has been approved by the Italian Ministry of Health [57]. Recently, Botta et al. [23] carried out ozone gas treatments in high concentrations (4,20 and 40 ppm) during the weekly closing days in red meat processing environments [23]. Another limitation of ozone treatment could be linked to the relative humidity of processing environments and foodstuffs. The bactericidal effect of gaseous ozone seems to be linked with high relative humidity [25], so this technology may be more effective in high humidity environments, while its action may be milder in low humidity conditions. Finally, although plastic materials commonly used in food industries, such as PTFE (Teflon), PVDF (Kynar), PVC (rigid and flexible) 
and ECTFE (Halar) exhibited good resistance to corrosion during the ozone exposure [27], further studies are needed to assess the potential effect of this technology on equipment after long treatment times.

\section{Conclusions}

Ozone gas in high concentration (50 ppm) was effective on L. monocytogenes planktonic cells, whereas its action in prevention and removal of L. monocytogenes biofilm was partial, strain-dependent and limited to the total biofilm biomass with a minimal effect on live adherent cells in the biofilm state. High concentrations of ozone gas are not sufficient to counteract $L$. monocytogenes biofilm. However, our results suggest that ozone gas may be applied as an additional tool against $L$. monocytogenes planktonic cells and to improve the existing sanitization procedures in food processing environments.

Author Contributions: F.P.: investigation, methodology, writing-original draft. S.R.: investigation, methodology, writing-review and editing. F.C.: formal analysis, investigation, writing-review and editing. T.C.: supervision, writing-review \& editing. P.A.D.C.: conceptualization, writing-review \& editing. All authors have read and agreed to the published version of the manuscript.

Funding: This work was supported by European Regional Development Funds (FESR 2014-2020_ D24I19000980002)—TECH4MILK.

Acknowledgments: The authors would like to thank the Biofresh Group Ltd. (Northumberland, UK) that provided the ozone equipment used for experiments.

Conflicts of Interest: The authors declare no conflict of interest.

\section{References}

1. González-Rivas, F.; Ripolles-Avila, C.; Fontecha-Umaña, F.; Ríos-Castillo, A.G.; Rodríguez-Jerez, J.J. Biofilms in the spotlight: Detection, quantification, and removal methods. Compr. Rev. Food Sci. Food Saf. 2018, 17, 1261-1276. [CrossRef] [PubMed]

2. Galié, S.; García-Gutiérrez, C.; Miguélez, E.M.; Villar, C.J.; Lombó, F. Biofilms in the food industry: Health aspects and control methods. Front. Microbiol. 2018, 9, 898. [CrossRef]

3. Abebe, G.M. The Role of Bacterial Biofilm in Antibiotic Resistance and Food Contamination. Int. J. Microbiol. 2020, 1705814. [CrossRef] [PubMed]

4. Skowron, K.; Wałecka-Zacharska, E.; Wiktorczyk-Kapischke, N.; Skowron, K.J.; Grudlewska-Buda, K.; Bauza-Kaszewska, J.; Bernaciak, Z.; Borkowski, M.; Gospodarek-Komkowska, E. Assessment of the Prevalence and Drug Susceptibility of Listeria monocytogenes Strains Isolated from Various Types of Meat. Foods 2020, 9, 1293. [CrossRef]

5. European Food Safety Authority and European Centre for Disease Prevention and Control (EFSA and ECDC). The European Union one health 2018 zoonoses report. EFSA J. 2019, 17, e05926. [CrossRef]

6. Buchanan, R.L.; Gorris, L.G.M.; Hayman, M.M.; Jackson, T.C.; Whiting, R.C. A review of Listeria monocytogenes: An update on outbreaks, virulence, dose-response, ecology, and risk assessments. Food Control 2017, 75, 1-13. [CrossRef]

7. Ricci, A.; Allende, A.; Bolton, D.; Chemaly, M.; Davies, R.; Fernández Escámez, P.S.; Girones, R.; Herman, L.; Koutsoumanis, K.; Nørrung, B.; et al. Listeria monocytogenes contamination of ready-to-eat foods and the risk for human health in the EU. EFSA J. 2018, 16, e05134. [CrossRef] [PubMed]

8. Colagiorgi, A.; Bruini, I.; di Ciccio, P.A.; Zanardi, E.; Ghidini, S.; Ianieri, A. Listeria monocytogenes biofilms in the wonderland of food industry. Pathogens 2017, 6, 41. [CrossRef]

9. Di Bonaventura, G.; Piccolomini, R.; Paludi, D.; D'Orio, V.; Vergara, A.; Conter, M.; Ianieri, A. Influence of temperature on biofilm formation by Listeria monocytogenes on various food-contact surfaces: Relationship with motility and cell surface hydrophobicity. J. Appl. Microbiol. 2008, 104, 1552-1561. [CrossRef]

10. Fagerlund, A.; Langsrud, S.; Møretrø, T. Microbial diversity and ecology of biofilms in food industry environments associated with Listeria monocytogenes persistence. Curr. Opin. Food Sci. 2021, 37, 171-178. [CrossRef]

11. Giaouris, E.; Heir, E.; Hébraud, M.; Chorianopoulos, N.; Langsrud, S.; Møretrø, T.; Habimana, O.; Desvaux, M.; Renier, S.; Nychas, G.J. Attachment and biofilm formation by foodborne bacteria in meat processing environments: Causes, implications, role of bacterial interactions and control by alternative novel methods. Meat Sci. 2014, 97, 298-309. [CrossRef] [PubMed]

12. Leong, D.; NicAogáin, K.; Luque-Sastre, L.; McManamon, O.; Hunt, K.; Alvarez-Ordóñez, A.; Scollard, J.; Schmalenberger, A.; Fanning, S.; O'Byrne, C.; et al. A 3-year multi-food study of the presence and persistence of Listeria monocytogenes in 54 small food businesses in Ireland. Int. J. Food Microbiol. 2017, 249, 18-26. [CrossRef]

13. Mazaheri, T.; Cervantes-Huamán, B.R.; Bermúdez-Capdevila, M.; Ripolles-Avila, C.; Rodríguez-Jerez, J.J. Listeria monocytogenes Biofilms in the Food Industry: Is the Current Hygiene Program Sufficient to Combat the Persistence of the Pathogen? Microorganisms 2021, 9, 181. [CrossRef] 
14. Oniciuc, E.A.; Likotrafiti, E.; Alvarez-Molina, A.; Prieto, M.; López, M.; Alvarez-Ordóñez, A. Food processing as a risk factor for antimicrobial resistance spread along the food chain. Curr. Opin. Food Sci. 2019, 30, 21-26. [CrossRef]

15. Martínez-Suárez, J.V.; Ortiz, S.; López-Alonso, V. Potential impact of the resistance to quaternary ammonium disinfectants on the persistence of Listeria monocytogenes in food processing environments. Front. Microbiol. 2016, 7, 638. [CrossRef]

16. Møretrø, T.; Schirmer, B.C.T.; Heir, E.; Fagerlund, A.; Hjemli, P.; Langsrud, S. Tolerance to quaternary ammonium compound disinfectants may enhance growth of Listeria monocytogenes in the food industry. Int. J. Food Microbiol. 2017, 241, $215-224$. [CrossRef]

17. Guérin, A.; Bridier, A.; Le Grandois, P.; Sévellec, Y.; Palma, F.; Félix, B.; LISTADAPT Study Group; Roussel, S.; Soumet, C. Exposure to quaternary ammonium compounds selects resistance to ciprofloxacin in Listeria monocytogenes. Pathogens 2021, 10, 220. [CrossRef]

18. Marino, M.; Maifreni, M.; Baggio, A.; Innocente, N. Inactivation of foodborne bacteria biofilms by aqueous and gaseous ozone. Front. Microbiol. 2018, 9, 2024. [CrossRef] [PubMed]

19. Colagiorgi, A.; Festa, R.; di Ciccio, P.A.; Gogliettino, M.; Balestrieri, M.; Palmieri, G.; Anastasio, A.; Ianieri, A. Rapid biofilm eradication of the antimicrobial peptide 1018-K6 against Staphylococcus aureus: A new potential tool to fight bacterial biofilms. Food Control 2020, 107, 106815. [CrossRef]

20. Meireles, A.; Borges, A.; Giaouris, E.; Simões, M. The current knowledge on the application of anti-biofilm enzymes in the food industry. Food Res. Int. 2016, 86, 140-146. [CrossRef]

21. Jiménez-Pichardo, R.; Hernández-Martínez, I.; Regalado-González, C.; Santos-Cruz, J.; Meas-Vong, Y.; Wacher-Rodarte, M.D.C.; Carrillo-Reyes, J.; Sánchez-Ortega, I.; García-Almendárez, B.E. Innovative Control of Biofilms on Stainless Steel Surfaces Using Electrolyzed Water in the Dairy Industry. Foods 2021, 10, 103. [CrossRef] [PubMed]

22. Zhu, Y.; Li, C.; Cui, H.; Lin, L. Feasibility of cold plasma for the control of biofilms in food industry. Trends Food Sci. Technol. 2020 99, 142-151. [CrossRef]

23. Botta, C.; Ferrocino, I.; Pessione, A.; Cocolin, L.; Rantsiou, K. Spatiotemporal distribution of the environmental microbiota in food processing plants as impacted by cleaning and sanitizing procedures: The case of slaughterhouses and gaseous ozone. Appl. Environ. Microbiol. 2020, 86, e01861-20. [CrossRef] [PubMed]

24. Sivaranjani, S.; Prasath, V.A.; Pandiselvam, R.; Kothakota, A.; Khaneghah, A.M. Recent advances in applications of ozone in the cereal industry. LWT 2021, 111412. [CrossRef]

25. Pascual, A.; Llorca, I.; Canut, A. Use of ozone in food industries for reducing the environmental impact of cleaning and disinfection activities. Trends Food Sci. Technol. 2007, 18, S29-S35. [CrossRef]

26. Pandiselvam, R.; Subhashini, S.; Banuu Priya, E.P.; Kothakota, A.; Ramesh, S.V.; Shahir, S. Ozone based food preservation: A promising green technology for enhanced food safety. Ozone Sci. Eng. 2019, 41, 17-34. [CrossRef]

27. Brodowska, A.J.; Nowak, A.; Śmigielski, K. Ozone in the food industry: Principles of ozone treatment, mechanisms of action, and applications: An overview. Crit. Rev. Food Sci. Nutr. 2018, 58, 2176-2201. [CrossRef] [PubMed]

28. Varga, L.; Szigeti, J. Use of ozone in the dairy industry: A review. Int. J. Dairy Technol. 2016, 69, 157-168. [CrossRef]

29. Sarron, E.; Gadonna-Widehem, P.; Aussenac, T. Ozone Treatments for Preserving Fresh Vegetables Quality: A Critical Review. Foods 2021, 10, 605. [CrossRef]

30. Harada, A.M.; Nascimento, M.S. Efficacy of dry sanitizing methods on Listeria monocytogenes biofilms. Food Control 2021, 124, 107897. [CrossRef]

31. Nicholas, R.; Dunton, P.; Tatham, A.; Fielding, L. The effect of ozone and open air factor on surface-attached and biofilm environmental Listeria monocytogenes. J. Appl. Microbiol. 2013, 115, 555-564. [CrossRef]

32. Robbins, J.B.; Fisher, C.W.; Moltz, A.G.; Martin, S.E. Elimination of Listeria monocytogenes biofilms by ozone, chlorine, and hydrogen peroxide. J. Food Prot. 2005, 68, 494-498. [CrossRef] [PubMed]

33. Giménez, B.; Graiver, N.; Giannuzzi, L.; Zaritzky, N. Treatment of beef with gaseous ozone: Physicochemical aspects and antimicrobial effects on heterotrophic microflora and Listeria monocytogenes. Food Control 2021, 121, 107602. [CrossRef]

34. Carpentier, B.; Cerf, O. Review-Persistence of Listeria monocytogenes in food industry equipment and premises. Int. J. Food Microbiol. 2011, 145, 1-8. [CrossRef]

35. Aalto-Araneda, M.; Pöntinen, A.; Pesonen, M.; Corander, J.; Markkula, A.; Tasara, T.; Stephan, R.; Korkeala, H. Strain variability of Listeria monocytogenes under $\mathrm{NaCl}$ stress elucidated by a high-throughput microbial growth data assembly and analysis protocol. Appl. Environ. Microbiol. 2020, 86, e02378-19. [CrossRef] [PubMed]

36. Bucur, F.I.; Grigore-Gurgu, L.; Crauwels, P.; Riedel, C.U.; Nicolau, A.I. Resistance of Listeria monocytogenes to stress conditions encountered in food and food processing environments. Front. Microbiol. 2018, 9, 2700. [CrossRef]

37. Hingston, P.; Chen, J.; Dhillon, B.K.; Laing, C.; Bertelli, C.; Gannon, V.; Tasara, T.; Allen, K.; Brinkman, F.S.L.; Hansen, L.T.; et al. Genotypes associated with Listeria monocytogenes isolates displaying impaired or enhanced tolerances to cold, salt, acid, or desiccation stress. Front. Microbiol. 2017, 8, 369. [CrossRef]

38. Lianou, A.; Nychas, G.J.E.; Koutsoumanis, K.P. Strain variability in biofilm formation: A food safety and quality perspective. Food Res. Int. 2020, 137, 109424. [CrossRef]

39. Piercey, M.J.; Ells, T.C.; Macintosh, A.J.; Truelstrup Hansen, L. Variations in biofilm formation, desiccation resistance and benzalkonium chloride susceptibility among Listeria monocytogenes strains isolated in Canada. Int. J. Food Microbiol. 2017, 257, 254-261. [CrossRef] 
40. Poimenidou, S.V.; Chrysadakou, M.; Tzakoniati, A.; Bikouli, V.C.; Nychas, G.J.; Skandamis, P.N. Variability of Listeria monocytogenes strains in biofilm formation on stainless steel and polystyrene materials and resistance to peracetic acid and quaternary ammonium compounds. Int. J. Food Microbiol. 2016, 237, 164-171. [CrossRef]

41. Harter, E.; Wagner, E.M.; Zaiser, A.; Halecker, S.; Wagner, M.; Rychli, K. Stress survival islet 2, predominantly present in Listeria monocytogenes strains of sequence type 121, is involved in the alkaline and oxidative stress responses. Appl. Environ. Microbiol. 2017, 83, e00827-17. [CrossRef]

42. Huang, Y.; Morvay, A.A.; Shi, X.; Suo, Y.; Shi, C.; Knøchel, S. Comparison of oxidative stress response and biofilm formation of Listeria monocytogenes serotypes $4 \mathrm{~b}$ and $1 / 2 \mathrm{a}$. Food Control 2018, 85, 416-422. [CrossRef]

43. Muhterem-Uyar, M.; Ciolacu, L.; Wagner, K.H.; Wagner, M.; Schmitz-Esser, S.; Stessl, B. New aspects on Listeria monocytogenes ST5-ECVI predominance in a heavily contaminated cheese processing environment. Front. Microbiol. 2018, 9, 64. [CrossRef] [PubMed]

44. Naditz, A.L.; Dzieciol, M.; Wagner, M.; Schmitz-Esser, S. Plasmids contribute to food processing environment-associated stress survival in three Listeria monocytogenes ST121, ST8, and ST5 strains. Int. J. Food Microbiol 2019, 299, 39-46. [CrossRef] [PubMed]

45. Ryan, S.; Begley, M.; Hill, C.; Gahan, C.G.M. A five-gene stress survival islet (SSI-1) that contributes to the growth of Listeria monocytogenes in suboptimal conditions. J. Appl. Microbiol. 2010, 109, 984-995. [CrossRef] [PubMed]

46. Henriques, A.R.; Fraqueza, M.J. Biofilm-forming ability and biocide susceptibility of Listeria monocytogenes strains isolated from the ready-to-eat meat-based food products food chain. LWT 2017, 81, 180-187. [CrossRef]

47. In Lee, S.H.; Barancelli, G.V.; de Camargo, T.M.; Corassin, C.H.; Rosim, R.E.; da Cruz, A.G.; Cappato, L.P.; de Oliveira, C.A.F. Biofilm-producing ability of Listeria monocytogenes isolates from Brazilian cheese processing plants. Food Res. Int. 2017, 91, 88-91. [CrossRef]

48. Stepanovic, S.; Vukovic, D.; Hola, V.; Di Bonaventura, G.; Djukic, S.; Ruzicka, F. Quantification of biofilm in microtiter plates: Overview of testing conditions and practical recommendations for assessment of biofilm production by staphylococci. Apmis 2007, 115, 891-899. [CrossRef]

49. Zand, E.; Pfanner, H.; Domig, K.J.; Sinn, G.; Zunabovic-Pichler, M.; Jaeger, H. Biofilm-Forming Ability of Microbacterium lacticum and Staphylococcus capitis Considering Physicochemical and Topographical Surface Properties. Foods 2021, 10, 611. [CrossRef] [PubMed]

50. BioRender. Available online: https:/ / biorender.com/ (accessed on 27 May 2021).

51. Guzzon, R.; Franciosi, E.; Carafa, I.; Larcher, R.; Tuohy, K.M. L'ozono, un innovativo strumento per il controllo microbiologico in aziende lattiero-casearie tradizionali. Ind. Aliment. 2015, 54, 11-15.

52. Djordjevic, D.; Wiedmann, M.; McLandsborough, L.A. Microtiter plate assay for assessment of Listeria monocytogenes biofilm formation. Appl. Environ. Microbiol. 2012, 68, 2950-2958. [CrossRef] [PubMed]

53. Kadam, S.R.; den Besten, H.M.W.; van der Veen, S.; Zwietering, M.H.; Moezelaar, R.; Abee, T. Diversity assessment of Listeria monocytogenes biofilm formation: Impact of growth condition, serotype and strain origin. Int. J. Food Microbiol. 2013, 165, 259-264. [CrossRef] [PubMed]

54. Nilsson, R.E.; Ross, T.; Bowman, J.P. Variability in biofilm production by Listeria monocytogenes correlated to strain origin and growth conditions. Int. J. Food Microbiol. 2011, 150, 14-24. [CrossRef] [PubMed]

55. Abeysundara, P.D.A.; Nannapaneni, R.; Soni, K.A.; Sharma, C.S.; Mahmoud, B. Induction and stability of oxidative stress adaptation in Listeria monocytogenes EGD (Bug600) and F1057 in sublethal concentrations of $\mathrm{H} 2 \mathrm{O} 2$ and NaOH. Int. J. Food Microbiol. 2016, 238, 288-294. [CrossRef] [PubMed]

56. Maggio, F.; Rossi, C.; Chaves-López, C.; Serio, A.; Valbonetti, L.; Pomilio, F.; Chiavaroli, A.P.; Paparella, A. Interactions between L. monocytogenes and P. fluorescens in Dual-Species Biofilms under Simulated Dairy Processing Conditions. Foods 2021, 10, 176. [CrossRef] [PubMed]

57. Bigi, F.; Haghighi, H.; Quartieri, A.; De Leo, R.; Pulvirenti, A. Impact of low-dose gaseous ozone treatment to reduce the growth of in vitro broth cultures of foodborne pathogenic/spoilage bacteria in a food storage cold chamber. J. Food Saf. 2021 , e12892. [CrossRef] 